\title{
RIPARIAN PLANT COMMUNITY STRUCTURE IN A MANAGED HYDROLOGICAL REGIME
}

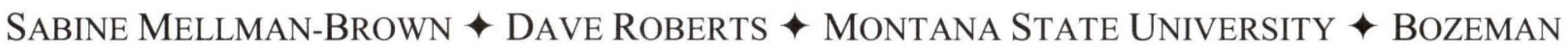 \\ BRuce PugeseK $\downarrow$ U.S.G.S $\downarrow$ Rocky Mountain Science CEnTER $\downarrow$ BOZEMAN
}

\section{$\uparrow \quad$ INTRODUCTION}

The hydrology of the Snake River in Grand Teton National Park is partly determined by releases from Jackson Lake Dam. The dam was first built in 1908 and became part of the National Park system when GTNP was expanded to include most of Jackson Hole. Completion of the present structure of Jackson Lake Dam occurred in 1917 and resulted in an increase above the natural level of Jackson Lake of $11.9 \mathrm{~m}$. The Bureau of Reclamation (BOR) manages the dam and sets discharge schedules, primarily to meet agricultural needs, and to a lesser extent the needs of recreational river use. Major changes to the hydrological regime of the Snake River include lower than natural peak releases, decrease in frequency of extreme flood events, and unusually high flows from July to September. In addition, peak releases prior to 1957 were not synchronized with spring runoff but shifted to July or early August. Changes in inundation frequencies of floodplains, inundation duration and timing of peak flows have profound effects on the extent and composition of the riparian zone.

\section{STUDY OBJECTIVES}

The main objective of this study is to characterize the riparian communities along the Snake River from Jackson Lake Dam to the southern border of Grand Teton National Park. We are hypothesizing that plant communities in the riparian zone are affected as a consequence of changes to the hydrological regime. Understanding key factors that determine the structure, composition and spatial distribution of riparian plant communities will allow us to create spatial models and predict changes to the riparian ecosystem resulting from current and future river management. The results of such models would allow managers to examine the implications of different dam operation scenarios on the riparian ecosystem.

Our research activities in 2006 aimed to:

- Complete the inventory of riparian plant communities along the Snake River. Establish vegetation study plots, identify all vascular plant species and estimate their cover. Record all tree regeneration and measure stem diameter and height of tree species. Collect environmental data on topography, relief, landform, substrate age, soils, browsing and habitat alteration.

- Define plant communities as they occur in the Snake River riparian zone.

- Relate environmental variables to observed vegetation pattern and explain spatial distribution of plant communities.

\section{$\downarrow \quad$ Findings AND STATUS}

During the field season 2006 we completed sampling of the riparian vegetation along the Snake River between Jackson Lake Dam and Moose. Combining the 2005 and 2006 data, we inventoried plant composition of 289 plots: 71 plots are located in the Oxbow area between Jackson Lake Dam and the confluence of Pacific Creek, another 109 are located between Pacific Creek and the boat launch at 
Deadman's Bar, and the remaining 109 sites are located between Deadman's Bar and Moose. Plot size varied from $10 \mathrm{~m}^{2}$ for herbaceous vegetation to $25 \mathrm{~m}^{2}$ and 100 $\mathrm{m}^{2}$ for shrubs and woodland, respectively. On each plot, all vascular plants were identified to species and their cover was estimated. Environmental data collected on each site included: height above water, distance from water, soil depth to gravel, slope, aspect, relief, animal activities, and other disturbances. These environmental data were complemented with geomorphological and hydrological maps created by Nick Nelson and Jack Schmidt from Utah State University, Logan.

We identified 314 vascular plant species in our 289 vegetation plots. Three of these species are considered sensitive in the State of Wyoming, namely Stephanomeria fluminea, Carex cusickii and Veronica scutellata. Another five species are on the noxious weed list for Grand Teton National Park: Carduus nutans, Cirsium arvense, Cirsium vulgare, Cynoglossum officinale and Tanacetum vulgare. While we notices a few scattered specimens of spotted knapweed (Centaurea maculosa) and toadflax (Linaria vulgaris) along the river, these widespread invasive species were infrequent in our study area and never encountered on our plots. A complete plant list, sensitive species occurrence records and UTM coordinates for plots with noxious weeds are available upon request*.

Vegetation composition of sites was analyzed with non-linear multidimensional scaling (NMDS). We used generalized additive models to link environmental variables with community composition. Height above water and depth to gravel are the best explanatory variables of vegetation composition along the river, with squared deviances of 0.62 and 0.59 , respectively. Surface age, as determined from maps showing channel change during the last 50 years, was also useful, achieving a squared deviance of 0.32 . While there is a strong relationship between distance to high water in spring, the same measurement in fall is a poor predictor for vegetation composition. These results document the relationship between hydrology, geomorphology and vegetation. Using discriminant analysis and/or structural equation modeling, we will further attempt to predict the spatial distribution and composition of riparian vegetation.

*http://webdev.uwyo.edu/uwnps/
We classified the riparian vegetation into 14 types, using a hierarchical cluster analysis approach with flexible beta. The distribution of these 14 types varies considerably between the three river sections. The moist sedge community in the Oxbow is characterized by Carex vessicaria - this type does not occur in the other two sections of the river. Tall willow vegetation in the Oxbow region is dominated by Salix boothii and is distinctly different to the tall willowalder shrubland found in the Pacific Creek and Deadman's Bar sections of the river. Most obvious are differences in young cottonwood stands: none of the four cottonwood regeneration types are common in the Oxbow.

Beside a lack of widespread cottonwood regeneration within the Oxbow section, cottonwoods are generally absent from the tall shrub and lower tree strata throughout the study area. We are hypothesizing that this constitutes evidence of past river management activities. Prior to 1957, peak releases from Jackson Lake Dam were shifted to July or early August, creating conditions not conducive to successful cottonwood regeneration. We are currently processing cottonwood diameter and age data to further examine influences of the altered hydrological regime on riparian forest structure along the Snake River. 